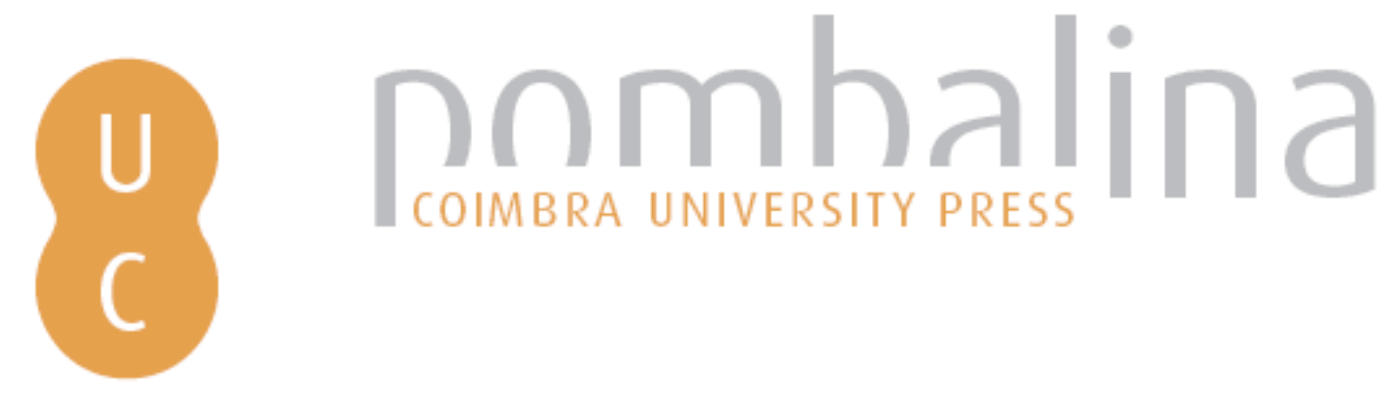

\title{
Quot lectiones, tot Turnebi: Adrien Turnèbe in recent editions of Plutarch's De animae procreatione
}

\author{
Author(s: $\quad$ Demulder, Bram \\ Published by: Imprensa da Universidade de Coimbra \\ Persistent URL: URI:http://hdl.handle.net/10316.2/41414 \\ DOI: $\quad$ DOl:https://doi.org/10.14195/978-989-26-1306-2_6 \\ Accessed : $\quad$ 23-May-2017 15:04:43
}

The browsing of UC Digitalis, UC Pombalina and UC Impactum and the consultation and download of titles contained in them presumes full and unreserved acceptance of the Terms and Conditions of Use, available at https://digitalis.uc.pt/en/terms_and_conditions.

As laid out in the Terms and Conditions of Use, the download of restricted-access titles requires a valid licence, and the document(s) should be accessed from the IP address of the licence-holding institution.

Downloads are for personal use only. The use of downloaded titles for any another purpose, such as commercial, requires authorization from the author or publisher of the work.

As all the works of UC Digitalis are protected by Copyright and Related Rights, and other applicable legislation, any copying, total or partial, of this document, where this is legally permitted, must contain or be accompanied by a notice to this effect. 


\section{Plutarque}

\section{Éditions, Traductions, Paratextes}

Françoise Frazier, Olivier Guerrier (coords.)

IMPRENSA DA UNIVERSIDADE DE COIMBRA 


\title{
QUOT LECTIONES, TOT TURNEBI \\ Adrien Turnèbe in recent editions of Plutarch's $D E$ ANIMAE PROCREATIONE ${ }^{1}$
}

\author{
Bram Demulder (bram.demulder@arts.kuleuven.be) \\ KU Leuven / Research Foundation - Flanders (FWO)
}

\begin{abstract}
Aвstract - Current critical editions of Plutarch's De animae procreatione frequently mention the contributions of Adrien Turnèbe (Adrianus Turnebus, 1512 - 1565) in their apparatus critici. Behind this single name hide different sources which should be acknowledged in their diversity. For Turnèbe's reading of De animae procreatione we can refer to the handwritten notes in his reading exemplar, his edition of the work, and his translation. These sources do not always present the same textual solutions. By discussing all passages from De animae procreatione where current editors refer to Turnèbe, I sketch this diversity of sources and point to some misunderstandings which arise when it is not taken into account.

KEY WORDS - De animae procreatione, edition, translation, marginalia, humanism, Renaissance
\end{abstract}

\section{INTRODUCTION}

If Montaigne's judgement is to be trusted, this paper brings together two of the greatest men in intellectual history: Plutarch and Adrien Turnèbe, or, as Montaigne lovingly calls them, 'nostre Plutarque' and 'mon Turnebus'. Plutarch, whom Montaigne knew through Amyot's translation', is lauded as 'si parfaict et excellent juge des actions humaines's. Montaigne was so deeply influenced by the Chaeronean's work that he had the feeling of 'le connoistre jusques dans l'ame's. This influence is clear throughout his Essais, where he refers to Plutarch's work over five hundred times ${ }^{6}$. Less ubiquitous but perhaps even more heartfelt is his appreciation for the humanist Adrien Turnèbe, who died fifteen years

${ }^{1}$ I would like to thank Geert Roskam and Xanne Huybrecht for their valuable suggestions.

2 'Nostre Plutarque': Essais I, 26 = Villey and Saulnier 1988: 156 (henceforth VS, preceded by the page number); II, 2 (p. 346 VS). 'Mon Turnebus': Essais II, 12 (p. 578 VS).

${ }^{3}$ Essais II, 4; see Guerrier 2014: 547. On Plutarch and Montaigne, see also Konstantinovic 1989 and Guerrier 2004.

${ }^{4}$ Essais II, 2 (p. 346 VS); cf. II, 31 (p. 714 VS): 'Plutarque est admirable par tout, mais principalement où il juge des actions humaines'.

${ }^{5}$ Essais II, 31 (p. 716 VS).

${ }^{6}$ Guerrier 2014: 547. In Essais I, 47 (p. 284 VS) Montaigne voices his appreciation for 'les mots mesmes de Plutarque, qui valent mieux que les miens'. Also important is Essais II, 32, where Montaigne launches a vigorous defence of Plutarch as a historian against the accusations of Bodin (cf. also II, 10 on Montaigne's appreciation for Plutarch as a historian). 
before the first edition of the Essais (1580) was published. In Du pédantisme Montaigne warmly praises Turnèbe as the prototypical opposite of the snobbish pseudo-intellectuals, who are targeted in this essay ("le plus souvent ils ne s'entendent ny autruy, et [...] ils ont la souvenance assez pleine, mais le jugement entierement creux'). Turnèbe is exceptional because his great learning - 'n'ayant faict autre profession que des lettres, en laquelle c'estoit, à mon opinion, le plus grand homme qui fut il y a mil' ans' - is free from any pedantry. This is what made him 'l'ame la plus polie du monde'. Elsewhere, Montaigne simply calls him 'Adrien Tournebu, qui sçavoit toutes choses'.

Adrien Turnèbe $(1512$ - 1565) started his career as a professor of Greek at the university of Toulouse in $1545^{\circ}$. On the death of his master Jacques Toussaint two years later, he returned to Paris, where he had studied, in order to become the Royal Reader in Greek at the Collège des lecteurs royaux (which is now the Collège de France). Subsequently, from 1561 until his death in 1565, he moved to the chair of Royal Reader in Greek and Latin Philosophy. Equally important was his appointment as Imprimeur royal pour les livres grecs, a position which he assumed in 1552. After four astonishingly productive years, he resigned from this post and was succeeded by his trustee Guillaume Morel.

Turnèbe's appointment as the royal printer marks the start of a prolific period in which he edited, translated, and commented a variety of classical texts, both pagan and Christian ${ }^{10}$. From his scientific accomplishments during this period and the years thereafter, it is clear that Turnèbe shared Montaigne's enthusiasm for Plutarch ${ }^{11}$. In 1552, his first year as royal printer, he published no less than four volumes of Plutarch: an edition and a translation of both De animae procreatione and De primo frigido. Four years later an annotated translation of De defectu oraculorum followed. In the posthumously published Opera omnia we find further translations of the Septem sapientium convivium and the spurious works De fato and De fuviis. Moreover, an autograph manuscript conserves a translation of De virtute et vitio.

${ }^{7}$ Essais I, 25 (p. 139 VS).

${ }^{8}$ Essais II, 23 (p. 440 VS). Montaigne also praises Turnèbe for his poetry and says that he 'sçavoit plus et sçavoit mieux ce qu'il sçavoit, que homme qui fut de son siecle, ny loing au delà' in Essais II, 17 (p. 661 VS). On the different ways of writing Turnèbe's name - Montaigne normally uses the Latinized name '(Adrianus) Turnebus', using the French 'Adrien Tournebu' only once - see Lewis 1998: 28-31.

${ }_{9}^{9}$ The definitive study about Turnèbe's bio-bibliography is Lewis 1998, on which I rely for the following paragraph.

${ }^{10}$ An exhaustive overview can be found in Lewis 1998: 105-212.

${ }^{11}$ While Plutarch may be Turnèbe's favourite Greek, his favourite author overall was undoubtedly Cicero. This latter appreciation was manifestly not shared by Montaigne; see e.g. Green 1975. 


\section{Turnèbe and Plutarch's De animae procreatione: a variety of SOURCES}

In what follows, I will focus on the mention of Turnèbe in the three critical editions of Plutarch's De animae procreatione which are commonly used today, i.e. the Teubner edition prepared by K. Hubert and corrected by H. Drexler (1959), H. Cherniss' edition in the Loeb Classical Library (1979), and the Italian edition in the Corpus Plutarchi Moralium by F. Ferrari and L. Baldi $(2002)^{12}$. My intention is to show that a variety of sources hides behind the name 'Turnebus' in our apparatus critici and that unawareness of this variety can give rise to misunderstandings concerning Turnèbe's intentions and - perhaps - to an underestimation of his philological and philosophical acumen $^{13}$.

First, therefore, we need to consider the different sources to which the name 'Turnebus' can possibly point. Two have already been mentioned. Both Turnèbe's translation and his edition of De animae procreatione appeared on the same day, 23 January 1552 . Whereas the translation was printed by Turnèbe himself as the new imprimeur royal, the edition was - quite remarkably - printed by Guillaume Morel. Nevertheless - and as the simultaneous publication already suggests - the two works are clearly intended as a pair, sharing the same illuminated upper border and a similar initial on the first page of text ${ }^{14}$. In the dedicatory letter preceding the translation, Turnèbe writes that he took up translating De animae procreatione while he was teaching Plato's Timaeus ${ }^{15}$. The edition does not offer paratextual material.

The most influential source of Turnèbe's reading of De animae procreatione, however, is neither his translation nor his edition, but the collection of scribbles in the margin of his own reading copy of Plutarch's Moralia, an exemplar of the 1509 edition printed in Venice by Aldus Manutius ${ }^{16}$. The reason for the

${ }^{12}$ Henceforth, I refer to all editions of De animae procreatione by the name(s) of the editor(s). The respective editions can be found in the first part of the bibliography. On the history of the text of the Moralia, including both the manuscript tradition and the editions, see Irigoin 1987. Wyttenbach 1795: lxxvii-cxxxv remains indispensable on the early editions. On renaissance translations see esp. Becchi 2009. For an introduction to De animae procreatione see Opsomer 2004.

${ }^{13}$ One important difference between our text of De animae procreatione and the text as it was received by Turnèbe and his contemporaries is the transposition of $1022 \mathrm{E}-1027 \mathrm{~F}$, which has been discovered only in the $19^{\text {th }}$ century. After $1017 \mathrm{C}$ all current editions print $1022 \mathrm{E}-1027 \mathrm{~F}$ before continuing with 1017C-1022E and 1027F-1032F. For discussion see Decorps-Foulquier 1982.

${ }^{14}$ The same border with similar initial reappears in both the translation and edition of De primo frigido, both of which were printed in the same year by Turnèbe himself. Of these publications we do not know the exact printing dates.

15 'Explicanti mihi Timaeum Platonis [...] venit in mentem commentarium Plutarchi in procreationem animi in Latinum convertere.'

${ }_{16}$ On the Aldine edition see Irigoin 1987: cclxxxvii-ccxcii. Turnèbe's copy is conserved in the Bibliothèque nationale de France (location: Rés-J-94) and was digitized in April 2015 (ark:/12148/bpt6k8586633). 
influence of these marginalia is that a selection made it into the index of the twovolume 1599 Frankfurt edition ${ }^{17}$. Unfortunately, as D. Wyttenbach was already aware, the report of the marginalia in the 1599 edition was done 'negligenter'18. Wyttenbach, moreover, was the first to remark that the marginalia were written in different hands ${ }^{19}$, only one of which should be identified as Turnèbe's, whereas the 1599 edition lists readings from all hands as being Turnèbe's. Scholarly discussion ensued, then, on which hand is in fact Turnèbe's. M. Cuvigny, discussing previous attempts to solve this question, concludes in desperation: 'Quant à $[. .$.$] designer exactement ce qui revient ou non à la main de Turnèbe, nous$ avouons en être absolument incapable' ${ }^{\prime 20}$. Only a few years later, however, M. Decorps-Foulquier convincingly identified 'la grosse écriture visible en marge' as Turnèbe's ${ }^{21}$, although there are instances where the difference between 'la grosse écriture' and the hand which she identifies as 'une écriture moyenne' is less clear than one would hope.

It has thus far been shown that a reference to Turnèbe in an edition of $D e$ animae procreatione can, at least theoretically, point to three different sources: the translation, the edition, or the notes in his Aldine copy. In the latter case, we need to be aware of the influence of the unreliable report of those readings in the 1599 Frankfurt edition and of the only quite recent identification of Turnèbe's hand among different other hands. In what follows, I will confront this variety of sources with what we find in current critical editions of Plutarch's treatise.

\section{TURNĖBE AND RECENT EDITIONS OF DE ANIMAE PROCREATIONE}

Before turning to the discussion of the passages where Turnèbe is adduced as a source in our recent critical editions of De animae procreatione, I want to make clear what the following discussion is not. First, it is not a full assessment of Turnèbe's textual criticism of this treatise. I am aware that, by starting from the mentions of Turnèbe in the apparatus critici of recent editions, I exclude the discussion of many of Turnèbe's marginalia and translational or editorial choices. Secondly, it is not a critique of the critical editions used here. I realize that it

${ }^{17}$ This is the edition to which the 'Stephanus' pages in our current editions refer. It is a reprint of Stephanus' original 1572 edition with, on the facing pages, reprints of Cruserius' 1564 translation of the Lives and Xylander's 1570 translation of the Moralia.

${ }^{18}$ Wyttenbach 1795: xcv: '[Q] $u$ uos [i.e. the editors of the 1599 edition] negligenter eo [i.e. the exemplum Turnebi] usos esse, plurimarum lectionum vel omissione vel vitiosa descriptione, infra ostendemus.'

${ }^{19}$ Wyttenbach 1795: xcv and Sturel 1908: 463-471 distinguish three different hands (cf. also Lewis 1998: 184). Cuvigny 1973: 65, however, rightly remarks that 'la distribution des variantes entre trois écritures simplifie arbitrairement les faits'. There are, indeed, at least four different hands at work (see also Decorps-Foulquier 1978: 282 with n. 2).

${ }^{20}$ Cuvigny 1973: 65.

${ }^{21}$ Decorps-Foulquier 1978. 
would not add to the practicality and usefulness of these editions if all issues discussed here were included, although it might be possible to show Turnèbe in more of his diversity than has been done hitherto ${ }^{22}$. My only intention is to point to the complexity hiding behind a seemingly simple reference in an apparatus and to invite the reader to appreciate this complexity.

\subsection{The Aldine marginalia vs the edition and translation}

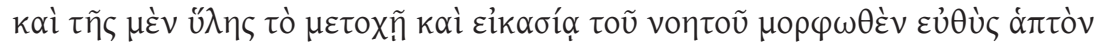

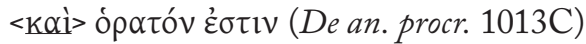

'[A]nd any matter that by participating in the intelligible and simulating it has got shape is straightway tangible <and> visible [...].' (tr. Cherniss $\left.{ }^{23}\right)$

Cherniss: <kail> -added by Xylander, implied by versions of Turnebus and Amyot

Hubert and Drexler: add. Turn. ${ }^{24}$

The insertion of kaí is not merely, as Cherniss has it, 'implied' by Turnèbe (i.e. in his translation), only to be explicitly added by Xylander in his 1574 edition. Both Turnèbe's edition and his translation (' $\&$ ') have it, so that there is no reason to suspect Turnèbe's intention to include it. One should write, like Hubert and Drexler: add[idit] Turn[ebus]. Turnèbe's Aldine edition has a koí written in the margin as well. However, it is clear that the hand is not Turnèbe's: the marginal note was added by a later owner of the book. How did a later addition, then, get into Turnèbe's edition and translation? Decorps-Foulquier discusses this particularly problematic case and suggests: 'l'auteur de ces leçons [i.e. the later owner of Turnèbe's copy] partageait peut-être avec Turnèbe éditeur la connaissance d'un manuscrit ou d'un recueil de variants perdu' ${ }^{25}$. Such speculation, however, is not necessary in this case: a philologist of Turnèbe's stature could easily have come up with this solution, perhaps based on the parallel later in the De animae procreatione ${ }^{26}$, on his first-hand knowledge of Plato's Timaeus, in which we find a parallel as well ${ }^{27}$, or simply on the logical assumption that the

${ }^{22}$ In a future edition one could, for instance, choose to designate different sigla to the three different Turnebian sources.

${ }^{23}$ All translations of De animae procreatione are taken from Cherniss' edition.

${ }^{24}$ As a rule, I will reproduce Cherniss' apparatus for the underlined words, only adding the apparatus of Hubert and Drexler and/or Ferrari and Baldi when they provide other or more information.

${ }^{25}$ Decorps-Foulquier 1978: 287.

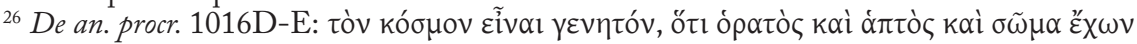

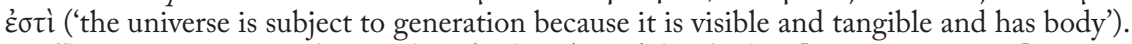

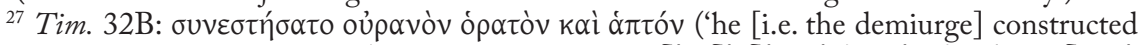

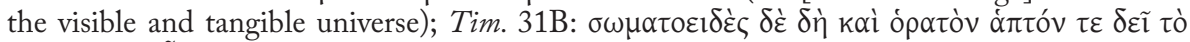

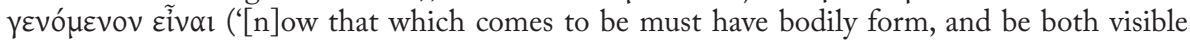




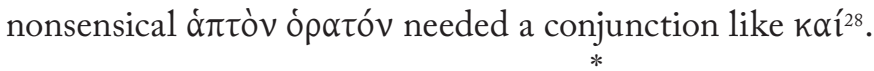

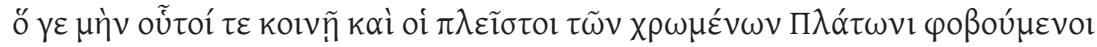

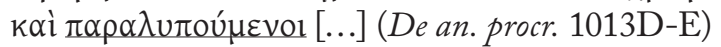

'In any case, what frightens and embarrasses these men [i.e. Xenocrates and Crantor, whose interpretations Plutarch has just refuted] in common with most of those who study Plato [...].'

Cherniss: $\pi \alpha \rho \alpha \mu \nu \theta o u ́ \mu \varepsilon v o 1-T u r n e b u s$.

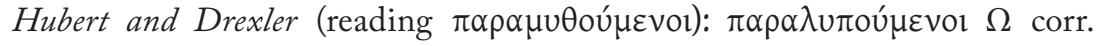
Turn.

Critical editions indicate that Turnèbe read $\pi \alpha \rho \alpha \mu \nu \theta o u ́ \mu \varepsilon v o r$ instead of the manuscript's $\pi \alpha \rho \alpha \lambda u \pi o u ́ \mu \varepsilon v o r$. Hubert and Drexler adopt this reading with the comment 'corr[exit] Turn[ebus]'. In Turnèbe's Aldine copy of Plutarch's works, we can indeed find the suggestion $\pi \alpha \rho \alpha \mu \nu \theta o ́ \mu \varepsilon v o r$ in margine in Turnèbe's hand. However, both in his edition ( $\pi \alpha \rho \alpha \lambda u \pi \circ u ́ \mu \varepsilon v o l)$ and in his translation ('anguntur') Turnèbe retains the manuscript (and Aldine) reading. About such cases in general, where Turnèbe's marginal correction is not reflected in his edition, Decorps-Foulquier hypothesizes that 'Turnèbe en a peut-être eu connaissance postérieurement à son édition'29. An equally probable hypothesis seems to me that there was, in Turnèbe's mind, a difference between a handwritten correction - perhaps made by the reader in a spur of the moment - and a printed correction and that, when preparing the edition, he just decided against some of the corrections he had made earlier. There is - as far as I can see - no reason to assume that the marginalia not featured in the edition were later additions. Moreover, one could ask why - although this argumentum e silentio is anything but decisive - these supposedly later corrections remained absent from Turnèbe's later magnum opus: throughout the 30 books of his Adversaria - a seemingly endless hotchpotch of readings and emendations of classical texts of all sorts - Plutarch is discussed several times, but there is no mention of $D e$ animae procreatione. To me it seems quite possible that the 1552 edition should be considered Turnèbe's final word on this text.

and tangible'; tr. Zeyl). We know from Turnèbe's dedicatory letter preceding his translation of the De animae procreatione and from his Praefatio in Timaeum preserved in his Opera omnia (III, 46-49) that Turnèbe lectured on the Timaeus. (Cf. supra n. 15)

${ }_{28}$ Decorps-Foulquier 1978: 286 remarks that there are seven other instances where marginalia from Turnèbe's Aldine copy which were not written by him reoccur in his edition. These instances are easily explained, as the author does: one could be taken from an earlier edition, two have identical solutions in marginalia which are written by Turnèbe and four are

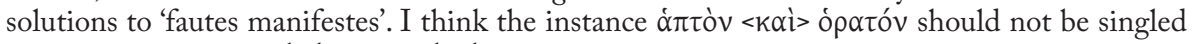
out as an exception: it belongs to the latter category.

${ }^{29}$ Decorps-Foulquier 1978: 286 n. 2. 


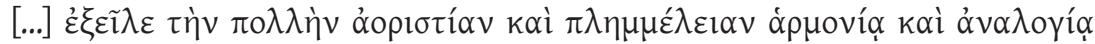

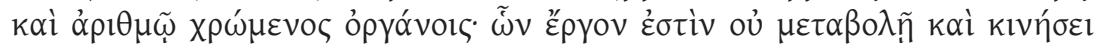

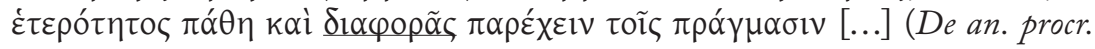
$1015 \mathrm{E}-\mathrm{F})$

'[The demiurge] removed the vast indefinitude and jangle [sc. from matter], using as tools concord and proportion and number, the function of which is not by change and motion to impart to things the modifications of diversity and difference [...].'

Cherniss: $\delta \propto \alpha \varphi \circ \rho \tilde{\alpha} \varsigma-H$. C. [i.e. an emendation proposed by Cherniss himself]

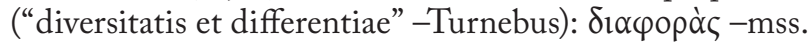

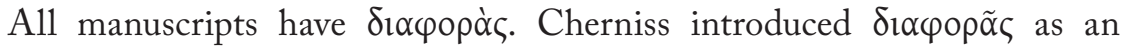
emendation of his own, although not without refering to Turnèbe's translation 'diversitatis et differentiae'. As opposed to a case which will be discussed later, the interpretation of the translation is correct. More importantly, however, full credit should have been given to Turnèbe, since he did include the (very plausible $^{30}$ ) emendation $\delta 1 \alpha \varphi \circ \rho \tilde{\alpha} \varsigma$ in his edition ${ }^{31}$. There is, however, no mention of an emendation in Turnèbe's Aldine copy, so that this reading was not - through the list in the 1599 edition - passed on to subsequent editions.

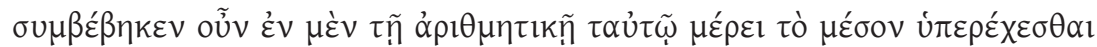

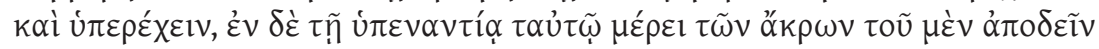

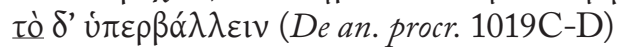

'So it is characteristic in the arithmetical [sc. mean] for the middle [sc. term] to exceed and fall short by the same fraction and in the subcontrary [sc. mean] for it to be inferior to one of the extremes and to surpass the other by the identical fraction of them [...]'?

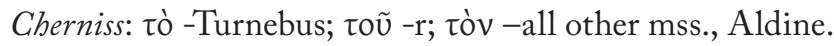

Cherniss' report seems to be - to phrase it rather irreverently - accidentally correct here. Since, in other cases, his references to Turnèbe's Greek text seem to be to the report of the marginalia in the 1599 Frankfurt edition, this is probably the case here as well. There we find indeed that Turnèbe read $\tau \dot{\mathrm{o}} \mu \dot{\varepsilon} v$

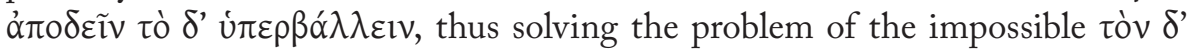
from the majority of the manuscripts, but creating a new problem by reading

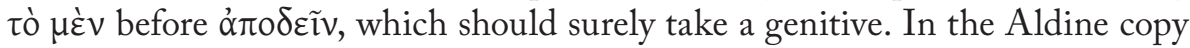

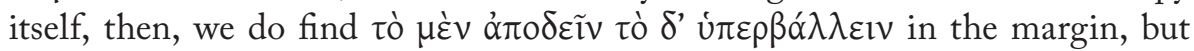
in a different hand than Turnèbe's, the 1599 report thus being incorrect here. Moreover, in Turnèbe's hand we can (albeit hardly) read toṽ, a reading which

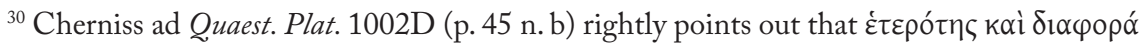
is a collocation which occurs quite frequently in Plutarch's philosophical works.

${ }^{31}$ Pace Ferrari and Baldi: 'corr[exit] Chern[iss]'.
} 


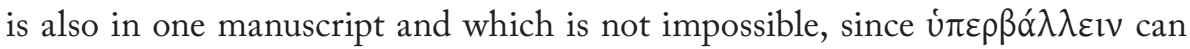
take a genitivus pro accusativo (LSJ q.v. II.2.b). In his edition, however, Turnèbe ultimately preferred to read $\tau$, thus printing the reading that is accepted today.

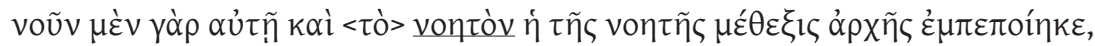

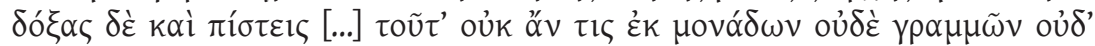

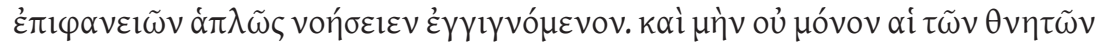

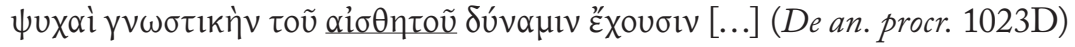
'Intelligence and intelligibility have been produced in her [i.e. the soul] by participation in the intelligible principle; but opinions and beliefs $[\ldots]$ there is not anyone who could conceive of this arising in her simply from units or from lines or surfaces. Now, not only do the souls of mortal beings have a faculty that is cognizant of the perceptible [...].'

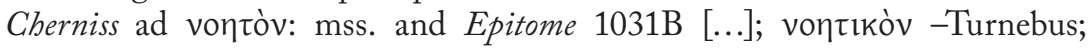
vónolv-Wyttenbach [...].

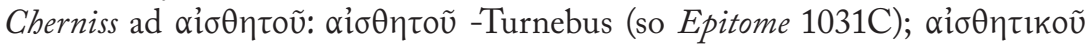
-mss.

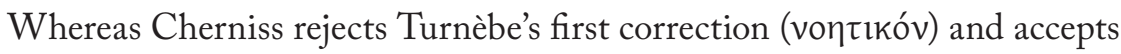
the second ( $\alpha i \sigma \theta \eta \tau o \tilde{u})$ (cf. also Ferrari and Baldi), Hubert and Drexler accept both Turnebian corrections. In the Aldine marginalia we indeed find the two corrections in Turnèbe's hand. In the edition, however, Turnèbe retains the manuscript readings in both cases ${ }^{32}$.

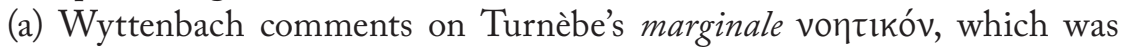
reported in the 1599 edition, that it has the advantage of having an active sense (i.e. 'the intellective'), as opposed to the manuscript reading ('the intelligible').

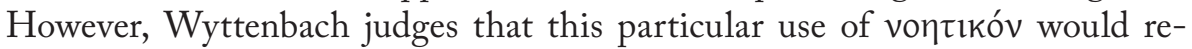
quire an article, so he rejects Turnèbe's marginal correction ${ }^{33}$. Wyttenbach's assumption that an active sense is necessary here, is - and this is what Cherniss seems to suggest in his translation - not correct: the active sense is covered by the mention of voũ and including the passive sense as well fits perfectly with Plutarch's philosophy ${ }^{34}$. Nevertheless, this does not seem to have been Turnèbe's reason for keeping the manuscript reading. His translation reads 'mentem enim

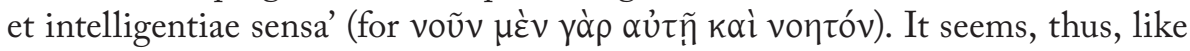
he assumed that vontóv could exceptionally take an active sense, which is not

${ }^{32}$ To my mind it is very unlikely that the reading preserved in the so-called Epitome, an excerpt of De an. procr. 1023B-1025B which is transmitted as a separate text in the corpus Plutarcheum, was a factor in Turnèbe's reasoning. Turnèbe's Aldine copy does not have a single marginale in Turnèbe's hand for the text of the Epitome.

${ }^{33}$ Wyttenbach: 'recepissem, si lectio, potius quam correctio videretur: hactenus placet, quod habet activam vim, quam locus requirit: sed item articulum requirit usus'.

${ }^{34}$ Cf. Quaest. Plat. 1002C-E. 
impossible per se (LSJ q.v. II), but which is never the case in De animae procre-

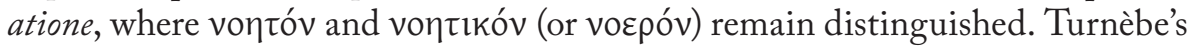
doubt and his ultimate decision to retain the manuscript reading are, however, understandable and correct.

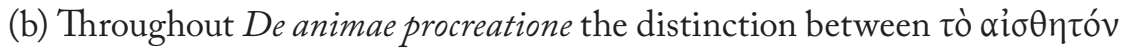

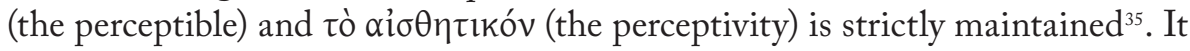

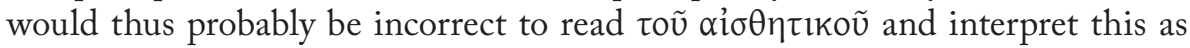
'of the perceptible', which seems clearly what is meant here. As appears from the translation, this is not what Turnèbe is doing in his edition. He translates: 'mortalium animi partis sentientis iudicio facultateque praediti sunt', thus un-

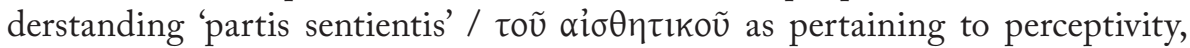
not perceptibility, and taking the genitive to express a specification of 'iudicio

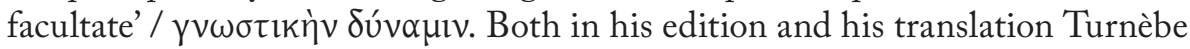
thus presents us with a reading which is far less evident with respect to the interpretation of the text, but attempts to save the manuscript reading.

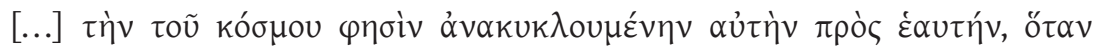

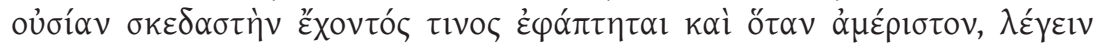

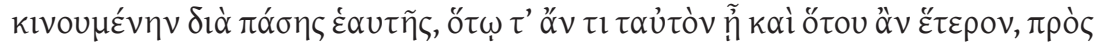

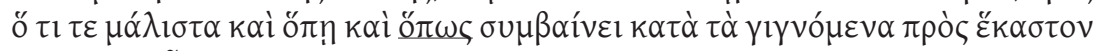

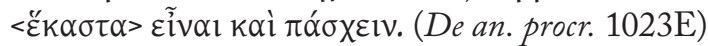

'[...] he [i.e. Plato] says that the soul of the universe also as she is revolving upon herself, whenever she touches anything that has being either dispersed or indivisible, is moved throughout herself and states of anything's being the same and different with regard to whatever it is so precisely the respect and context and manner of its happening to be or to have as attribute <either of these> in relation to each among the things that come to be.'

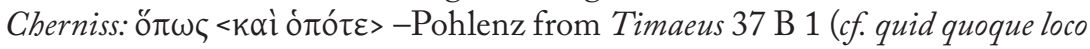
aut modo aut tempore -Turnebus).

An example of a correction inspired by Turnèbe's knowledge of Plato's Ti-

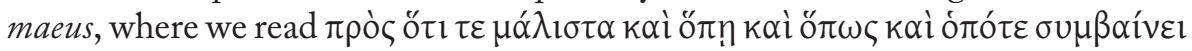
(Tim. 37B). Whether or not this insertion should be accepted, Cherniss (and the other recent editors) should have given more credit to Turnèbe for proposing it. Not only does it occur in his translation - like in other cases where Plutarch cites the Timaeus, Turnèbe actually quotes from Cicero's Timaeus translation - but also in the edition. Since there is no marginal note in the Aldine exemplar - and, consequently, the correction was not transmitted through the 1599 Frankfurt edition - this has not been acknowledged in recent editions. As to

${ }^{35}$ This is not the case for the entire corpus Plutarcheum. See e.g. De cap. ex inim. 90B (with

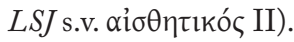


the correctness of the insertion, I remain undecided. Given the fact that this is a rather confusing passage featuring a stack of question words, it is possible that

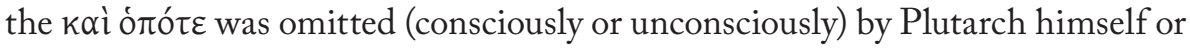
somewhere in the manuscript tradition.

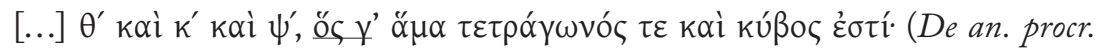
1028B)

'[...] 729, which is at the same time a square and a cubic number [...]'.

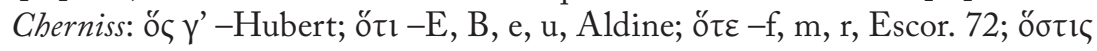
-Stephanus ("qui numerus" - Turnebus).

There is no marginale in the Aldine copy. The reading ö $\sigma \tau \iota \varsigma$ does appear however in Turnèbe's edition, and Stephanus may have adopted it from there or from Turnèbe's translation, which he printed along with his own edition of $D e$ animae procreatione in his 1572 edition. Hubert's solution may be more elegant, but Turnèbe's suggestion certainly improves upon the manuscript readings.

Considering all marginalia in general, Decorps-Foulquier remarks that '[1'] édition [...] témoigne d'un effort de correction plus complet que les annotations de l'exemplaire qui reviennent à Turnèbe ${ }^{36}$. I think all passages discussed here can be considered examples of this general rule: between his reading notes and his published works, Turnèbe added but also rejected corrections.

\subsection{Translation vs edition}

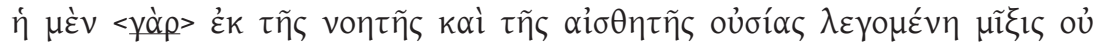

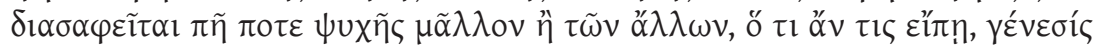

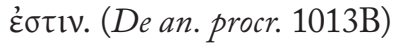

'<For>, as to what the one party calls the mixture of the intelligible and the perceptible being, it is not made clear how in the world this is generation of soul rather than of anything else one may mention [...].'

Cherniss: < $\gamma \alpha \grave{\rho}>$ added by Maurommates ("nam" -Turnebus; "car"-Amyot).

The insertion of yó $p$ is found first in Maurommates' 1848 edition. Cherniss mentions Turnèbe, who translates 'nam', as a predecessor of this solution. However, neither in Turnèbe's Aldine copy nor in his edition a trace of yó $\rho$ can be found. In the reading copy nothing is mentioned in margine. In the edition, however, Turnèbe shows awareness of a missing particle, but he inserts oũv. Although Turnèbe exhibits great variation in translating oṽv - he uses more than ten synonyms throughout his translation of De animae procreatione (igitur, ergo,

\footnotetext{
${ }^{36}$ Decorps-Foulquier 1978: 287 n. 1.
} 
itaque, proinde, ...) - it seems unlikely that he intended the causal connector nam as a translation for the virtually opposite, consecutive connector oũv. In any case, nam / үó p is obviously the best choice if the structure of Plutarch's argument is taken into account: what follows after yó $\rho$ is an explanation of why - as was stated in the previous sentence - Plutarch's rival interpreters are mistaken. I cannot but wonder why Turnèbe did not match his translational conjecture with his editorial conjecture. Did he possess a witness which read oũv?

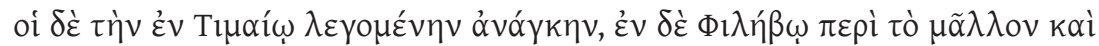

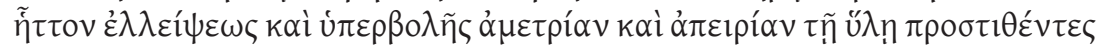

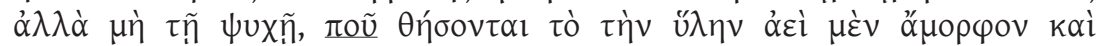

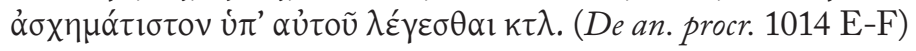

'Those, however, who attribute to matter and not to soul what in the Timaeus is called necessity and in the Philebus measurelessness and infinitude in the varying degrees of deficiency and excess, what will they make of the fact that by Plato matter is said always to be amorphous and shapeless [...]?'

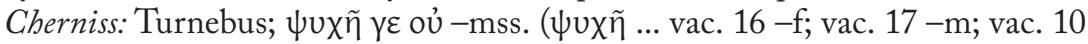
$-\mathrm{r} \ldots \gamma \varepsilon$ oủ).

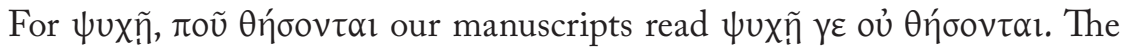
Aldine edition, however, along with three 16th-century manuscripts which go back to the same hyparchetype as Aldus' edition ${ }^{37}$, posit a lacuna between $\psi v x \tilde{n}$ and $\gamma \varepsilon$ oủ. The change from $\gamma \varepsilon$ oủ to $\pi$ ov is attributed to Turnèbe by our current editions $^{38}$ and is indeed found in Turnèbe's Aldine copy, where in his quirky

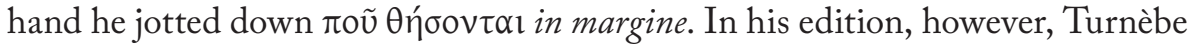
retains the Aldine reading, perhaps incorrectly suspecting the lacuna to antedate the textual corruption to $\gamma \varepsilon$ ou. In the translation, on the other hand, the conjecture written in the margin of his Aldine exemplar is used ('quo tandem modo tuebuntur', aptly rendering the exasperation included in the question word $\pi$ ov with 'tandem' ${ }^{39}$ ).

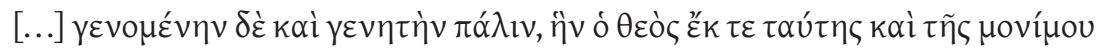

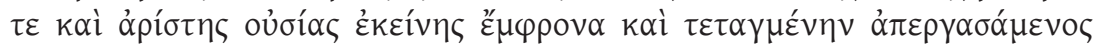

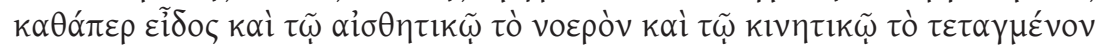

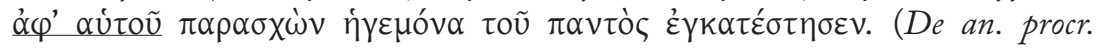
1016C)

'[...] come to be and so subject to generation is said on the other hand of soul that god installed as chief of the sum of things when out of this soul here and that abiding and most excellent being yonder he had produced a rational and

\footnotetext{
${ }^{37}$ See the stemma in Hubert and Drexler 1959: xvii.

${ }^{38}$ Hubert and Drexler: 'corr[exit] Turn[ebus]'.

${ }^{39}$ LSJ q.v. II: $\pi$ ov used in 'indignant questions'.
} 
orderly one and from himself had provided intellectuality and orderliness as form for her perceptivity and motivity.'

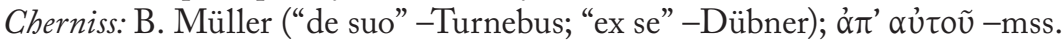

It seems impossible to retain the manuscript reading $\alpha \dot{\alpha} \pi^{\prime} \alpha \hat{v} \tau o \tilde{v}$ and make philosophical sense of the text. Müller, in his 1873 edition, prints the reflexive form $\alpha \varphi^{\prime} \alpha \dot{v} \tau o \tilde{v}$ for the first time, without reference to predecessors in his apparatus. This rather evident solution is adopted by all subsequent editions. Earlier translations, however, show awareness of a problem: Xylander did not translate $\alpha \dot{\pi}$ ' $\alpha \dot{\tau} \tau o \tilde{v}$ and Cherniss mentions the translations of Turnèbe ('de suo') and

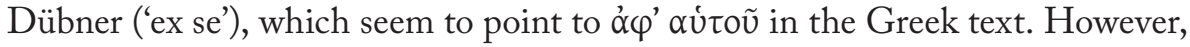
just like Dübner, Turnèbe did not alter the Greek text: neither his edition nor

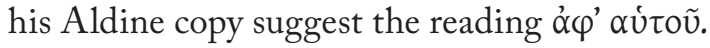

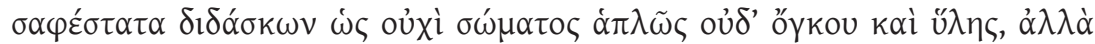

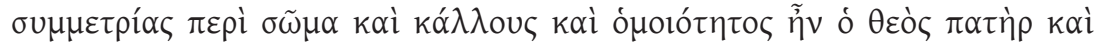

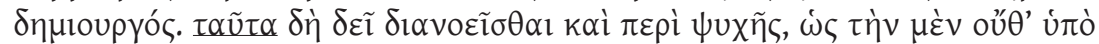

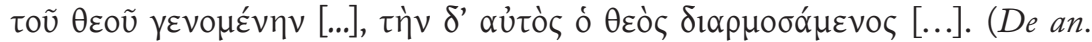
procr. 1017A-B)

'So he [i.e. Plato] most manifestly teaches that god was father and artificer not of body in the absolute sense, that is to say not of mass and matter, but of symmetry in body and of beauty and similarity. This, then, is what one must suppose in the case of soul also, that, whereas the one neither was brought into being by god [...], the other was regulated by god himself [...].'

Cherniss: $\tau \alpha u ̉ \tau \grave{\alpha}-$ Hubert (dub., cf. "quod idem ..." -Turnebus).

All current editions follow the manuscript reading $\tau \alpha \tilde{v} \tau \alpha$, although the emendation $\tau \alpha \hat{u} \tau \dot{\alpha}$ has been proposed dubitanter by the editor of the Teubner edition. Cherniss refers to Turnèbe's translation ('idem') as a predecessor of this solution. Again, Turnèbe's edition retains the manuscript reading ${ }^{40}$. There is no marginal note in the Aldine exemplar. Any judgement on this passage will probably remain - like Hubert's - dubitanter, since both readings make perfect

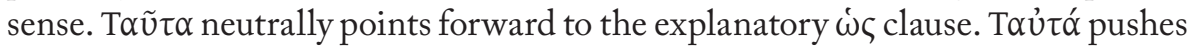
Plutarch's interpretation a bit more, since it emphasizes the parallel between the construction of the cosmic body and the cosmic soul, a key feature of Plutarch's exegetical efforts in this treatise. One could argue, however, that the parallelism

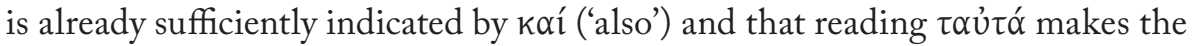
sentence a little pleonastic.

${ }^{40}$ The same line, however, does have two marginal corrections to the Aldine reading ("̆v ó $\theta \varepsilon \dot{\varsigma} \varsigma$ corrected to $\tilde{\eta} v$ ó $\theta \varepsilon \dot{c} \varsigma ; \tau \alpha \tilde{u} \tau \alpha \delta \dot{\eta}$, corrected to $\tau \alpha \tilde{v} \tau \alpha \delta \varepsilon \tilde{\imath})$. The same adjustments occur in Turnèbe's edition, but in my (duly cautious) opinion, the marginal corrections are not written in Turnèbe's hand. 


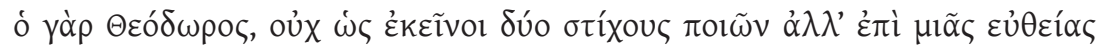

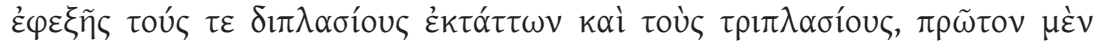

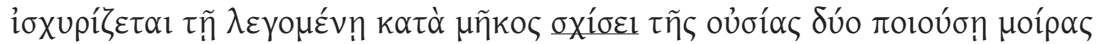

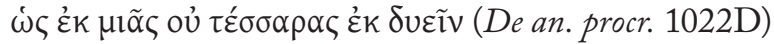

'For Theodorus unlike those others [i.e. Crantor and Clearchus] does not make two rows but sets out the double and the triple numbers one after another in a single, straight line, relying for this in the first place upon what is stated to be the cleavage of the substance lengthwise that makes two parts presumably out of one, not four out of two [...].'

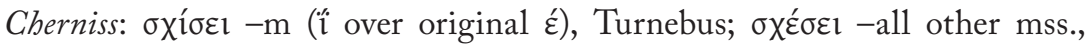
Aldine.

Once again, this seems to be an unproblematic correction: we find it in Turnèbe's hand in the Aldine copy as well as in the edition. The validity of the correction cannot be doubted, since we are dealing here with a clear reference to Timaeus 36B, where it is described how the world soul is sliced in two along

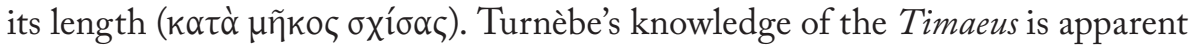
here. However, the translation poses a puzzling problem here: Turnèbe translates the manuscript (and Aldine) reading $\sigma \chi \varepsilon$ $\sigma \varepsilon l$ instead of his own correction: 'Ac primum quidem nititur illo naturae habitu qui in porrectum dicitur.' I am at a loss to explain Turnèbe's choice of translation here. Was it perhaps just a translational lapsus?

The previous examples have shown that, in Turnèbe's mind, a translation was fundamentally different from an edition, while current editions refer to the edition and translation indiscriminately in order to report Turnèbe's view on the constitutio textus. In general, it should be kept in mind that Turnèbe allowed himself more liberty in the translation, while being more conservative in the edition.

\subsection{Turnèbe wrongly reported}

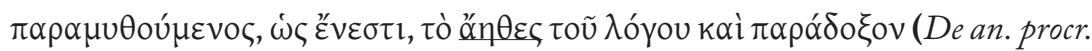
$1014 \mathrm{~A})$

'[...] vindicating as far as may be by probability what is unusual and paradoxical about my account [...]'

Cherniss: Wyttenbach (after the versions of Turnebus and Amyot); $\alpha \lambda \lambda \theta \dot{\varepsilon} \varsigma$ -mss.

A peculiar consequence of the greater freedom Turnèbe allowed himself while translating the text can be deduced from this example. All manuscripts have $\alpha \lambda \eta \eta \dot{\varepsilon} \zeta$ instead of ${ }^{\alpha} \eta \theta \varepsilon \varsigma$, Wyttenbach's conjecture which is accepted by 
all critical editions. Wyttenbach was particularly pleased with this conjecture, calling it 'certissima' but giving part of the credit to Turnèbe ('jam Turnebus vertit'). Wyttenbach indicates that Turnèbe's conjecture can be found in his translation. Indeed, there is no marginal note in Turnèbe's reading exemplar and his edition preserves the manuscript reading $\alpha \hat{\lambda} \eta \theta \dot{\varepsilon} \varsigma$. However, I doubt that Turnèbe had a conjecture on his mind when translating this passage. He translates: 'ex verae rationis insolentia et admirabilitate, quoad eius facere potero, deonerans'. Wyttenbach probably saw 'insolentia' as an implied insertion of än $\theta \varepsilon \varsigma$. However, Turnèbe, like his idol Cicero, constantly opts for paraphrasing one Greek word by two Latin words. To my mind, 'insolentia et admirabilitate' is Turnèbe's translation of the single word $\pi \alpha \rho \alpha ́ \delta \circ \xi o v$, intended to bring out two connotations included in the one Greek word. Taking 'insolentia' as a rendering of a conjecture ö $\eta \theta \varepsilon \varsigma$ would make it hard to account for the presence of the adjective 'verus' in Turnèbe's translation: with $\lambda$ ó Plutarch refers to his account without any explicit claim as to its truth value. Elsewhere, Turnèbe understands this correctly and translates accordingly ${ }^{41}$. That the matter is less clear in this case is due to the fact that Turnèbe got into syntactic problems by interpreting $\pi \alpha \rho \alpha \mu \nu \theta \varepsilon$ c $\mu \alpha 1$ as 'deonerare' ('to remove a burden, unload', $O L D$ q.v.), taking his inspiration for using this very rare Latin verb from - of course - Cicero ${ }^{42}$. This rendering of $\pi \alpha \rho \alpha \mu \nu \theta \varepsilon \varepsilon_{0} \mu \alpha l$ is very well possible ${ }^{43}$, but it would evidently be absurd to claim to unload the truth. Thus, Turnèbe, aware of the fact that the semantic range of $\pi \alpha \rho \alpha \mu \nu \theta \varepsilon \dot{\varepsilon} \mu \alpha \_$is broader than that of deonerare ${ }^{44}$, chose to alter the syntax in his translation which he rarely does - and to translate $\tau \dot{\alpha} \alpha \hat{\alpha} \eta \eta \dot{\varepsilon} \varsigma$ as if it were dependent on

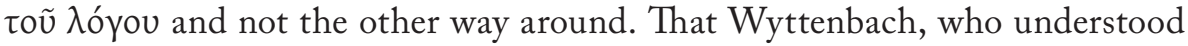
$\pi \alpha \rho \alpha \mu v \theta \varepsilon \dot{\varepsilon} \mu \alpha \mathrm{l}$ in the same way, took the inspiration for his conjecture $\alpha^{\prime} \eta \varepsilon \varsigma \varsigma$

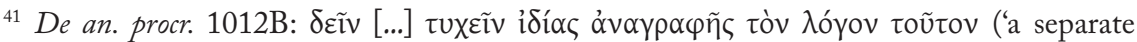
treatise ought to be devoted to this account'), Turnèbe: 'suaque privatim scriptione rem istam

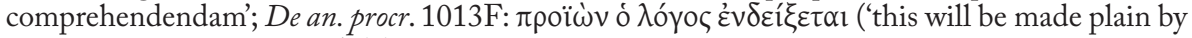
our account as it proceeds'), Turnèbe: 'progressus orationis monstrabit'. One could object that

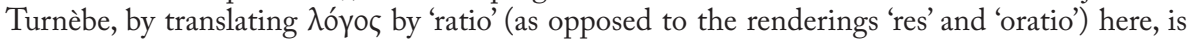
thinking of another, more philosophical meaning of $\lambda$ ó

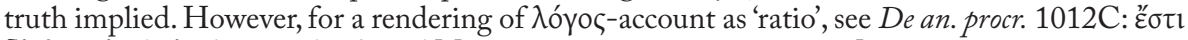

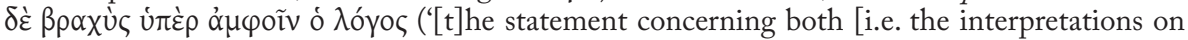
the generation of the world soul by Xenocrates and Crantor] is concise'), Turnèbe: '[a]c certe perbrevis est utriusque ratio'. See also De an. procr. 1023E, where Timaeus 37B ( $\lambda$ ópos [...] $\grave{\alpha} \lambda \eta \theta \eta ́(\varsigma)$ is quoted and Turnèbe translates - or, rather, quotes from Cicero's Timaeus translation - 'ratio $[\ldots]$ vera'.

${ }^{42}$ Cic., Div. Caec. 46: 'cum [...] ex illius invidia deonerare aliquid et in te traicere coeperit'. (Note the similar construction of 'deonerare' with 'ex'.)

${ }^{43}$ LSJ q.v. 3: 'relieve, assuage, abate'.

${ }^{44}$ LSJ q.v. 5: 'support, justify'. Cf. De an. procr. 1012B: $\delta \varepsilon o ́ \mu \varepsilon v o v ~ \pi \alpha \rho \alpha \mu v \theta i ́ \alpha \varsigma$ ('in need of vindication'), Turnèbe: 'subsidii firmamentique indigentem'. (This is at the same time an example of Turnèbe's habit of translating one Greek word by two Latin words.) 
from reading Turnèbe's translation is understandable, but the (in my opinion unnecessary ${ }^{45}$ ) conjecture itself is to his credit alone.

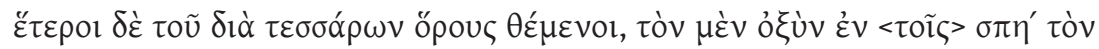

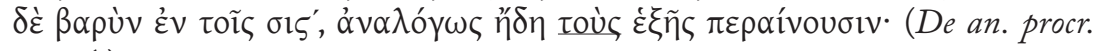
$1022 \mathrm{~A})$

'As terms of the fourth, however, others put the high note at 288 and the low at 216 and then determine proportionally those that come next [...].'

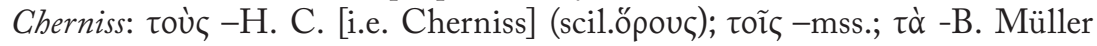
(1873), cf. "reliqua" in the versions of Turnebus and Xylander.

Turnèbe's translation indeed shows that he took the complement of

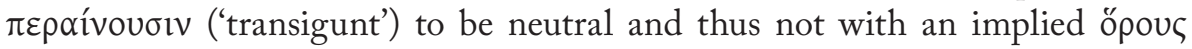
(the masculine 'finis'). However, there is no marginal correction to the Aldine

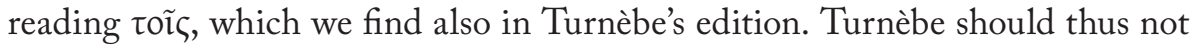
be adduced as a predecessor to Müller's reading.

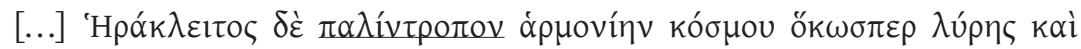
тółov [...] (De an. procr. 1026B)

'Heraclitus [calls destiny] concord of the universe retroverse like that of lyre and bow.'

Cherniss: mss. [...]; $\pi \alpha \lambda i ́ v \tau$ tovov-Turnebus.

This is an example of the problematic report of Turnèbe's marginalia in the 1599 Frankfurt edition, which mentions $\pi \alpha \lambda i$ iv tion. We find $\pi \alpha \lambda i ́ v \tau o v o v$ written in margine in a hand which is definitely not Turnèbe's: the correction has been added by a later owner of the exemplar. In his edition Turnèbe prints $\pi \alpha \lambda i ́ v \tau \rho o \pi o v$, which is also reflected in his translation ('intentionem [...] refugam'). For the Heraclitus fragment in question (fr. B51 DK) $\pi \alpha \lambda i ́ v \tau o v o \zeta$ and $\pi \alpha \lambda i ́ v \tau \rho o \pi \circ$ seem to be ancient variants and Plutarch seems to have been aware of this, using the former in De Iside et Osiride (369B)

${ }^{45}$ This is not the place to discuss this textual issue extensively, but I see no real problem with keeping the manuscript reading $\dot{\alpha} \lambda \eta \theta \dot{\varepsilon} \zeta$ and translating 'vindicating as far as may be by probability the truth of my account and [i.e. including] the paradoxical aspect of it'. (For tò

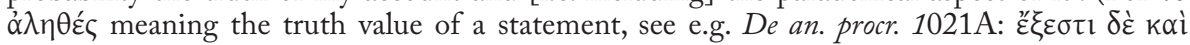

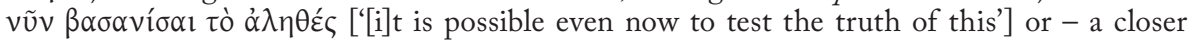

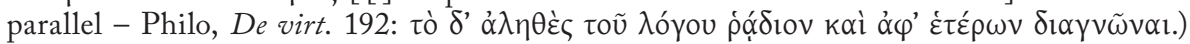
This interpretation means that we should take $\pi \alpha \rho \alpha \mu v \theta \varepsilon \dot{\varepsilon} 0 \mu \alpha$ to mean 'justify' (LSJ q.v. 5) and not 'abate' (LSJ q.v. 3), as Turnèbe and Wyttenbach took it. That this is possible and even preferential is shown by the first sentence of De an. procr. (1012B), where Plutarch presents

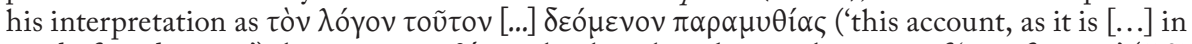
need of vindication'): here, $\pi \alpha \rho \alpha \mu \nu \theta i \alpha$ is clearly to be taken in the sense of 'justification' (LSJ q.v. 4: 'explanation') and not 'relief from, abatement of' (LSJ q.v. 3). 
and the latter here as well as in De tranquillitate animi $(473 \mathrm{~F}-474 \mathrm{~A})^{46}$. Turnèbe, in any case, certainly read $\pi \alpha \lambda$ ív $\tau \rho \circ \pi \circ v$ here.

\subsection{Turnèbe's conjectures}

In the remaining cases Turnèbe's marginalia, his edition, and his translation are in accord.

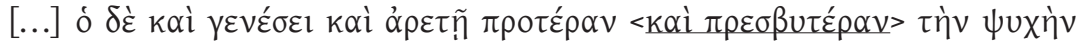

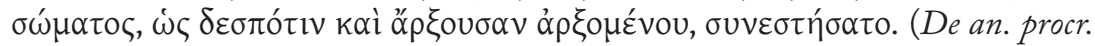
1016B)

' $[\mathrm{H}]$ e constructed the soul prior <and senior > to body in generation and excellence to be mistress and ruler of it as her subject.'

Cherniss: $<\ldots .>$ added by Turnebus from Timaeus 34 c $4-5$ [...]

We find Turnèbe's emendation in the margin of his Aldine copy, in his edition, and in his translation. This addition is a testimony to Turnèbe's excellent knowledge of Plato's Timaeus: Plutarch is quoting Tim. 34C ${ }^{47}$. The (probably correct ${ }^{48}$ ) addition is all the more remarkable since Cicero, on whose partial translation of the Timaeus Turnèbe heavily depends for his own translation,

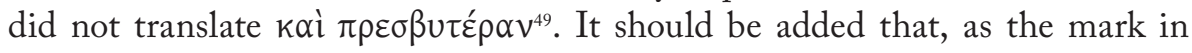
the text of the Aldine copy indicates, Turnèbe intended the insertion of kai

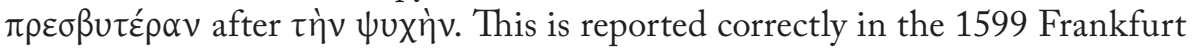
edition and Turnèbe adopts the same word order - contra Plato's Timaeus - in his edition. Did he complete the Timaeus quote from memory or did he have a Timaeus text which had a different word order than our textus receptus?

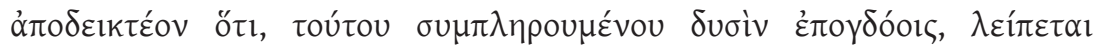

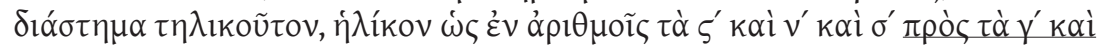
$\mu^{\prime}$ kai $\sigma^{\prime}$. (De an. procr. 1021E)

'It is to be proved that, when this is filled in with two sesquioctaves, there is left an interval of the size that numerically expressed is 256 to 243.'

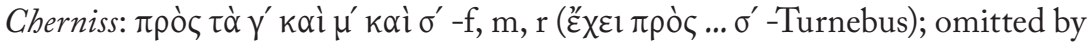
E, B, e, u, Escor. 72, Aldine.

\footnotetext{
${ }^{46}$ For discussion of Plutarch's usage see Cherniss ad loc. For discussion of the variants in the Heraclitus fragment see e.g. Kirk 1954: 210-215.

${ }^{47}$ The only difference between Plato's text as we have it and Plutarch's quote is that Plato does not have an article before $\psi u x \eta ́ v$.

${ }^{48}$ One could object that Plutarch misquoted Plato and that, therefore, the manuscript reading (i.e. the incorrect quotation from the Timaeus) should be retained. However, Cherniss

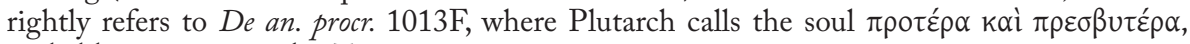
probably anticipating the Timaeus quote.

${ }^{49}$ Cicero, Timaeus 21: 'deus autem et ortu et virtute antiquiorem genuit animum [...]'.
} 
Although the content of this sentence on the mathematical division of the world soul may be puzzling to the reader not familiar with the context in which it appears, this correction is more or less straightforward. It occurs in Turnèbe's hand in the marginal note and is reported correctly in the 1599 Frankfurt edition. Moreover, he included it in his edition and translated it. Turnèbe may have taken it from one of the manuscripts that have the correct text: three 16th-century manuscripts with the correct reading are known to us. However, it seems more likely to me that Turnèbe inferred the correct reading from the context: this would explain his addition of Ex$\varepsilon \mathrm{l}$, absent from the manuscripts but occurring a few lines earlier ${ }^{50}$.

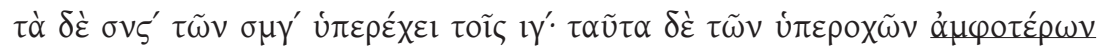

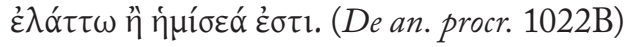

' 256 exceeds 243 by thirteen, which is less than half of both the excesses 32 and 27.'

Cherniss: Turnebus; $\alpha \mu \varphi o ́ \tau \varepsilon p \alpha-e, u, f, \mathrm{~m}, \mathrm{r}$, Escor. 72, Aldine; $\alpha \mu \varphi o ́ \tau \varepsilon \rho \alpha$ after $\dot{u} \varepsilon \varepsilon \rho \circ \chi \tilde{\omega} v-\mathrm{E}, \mathrm{B}$.

This case is very similar to the previous one. Again, the correction must have been quite easily inferred from the context by a man with Turnèbe's philological and philosophical acumen. It occurs in his hand in the Aldine copy, it reappears in the edition, and it is translated accordingly.

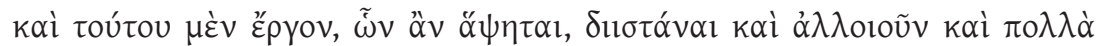

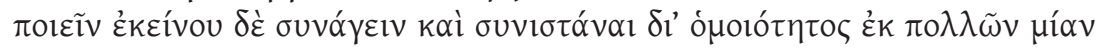

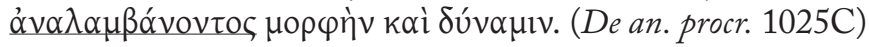

'[T]he function of the latter [i.e. difference] is to divide and diversify and make many whatever it touches but of the former [i.e. sameness] is to unite and combine, recovering from many by means of similarity a single form and force.'

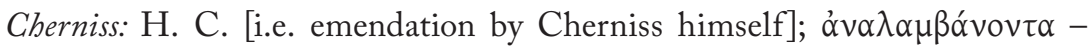
mss.; $\alpha$ $v \alpha \lambda \alpha \mu \beta \alpha v o ́ v \tau \omega v$-Turnebus, Stephanus.

The manuscript reading, which requires taking $\alpha \dot{\alpha} \alpha \lambda \alpha \mu \beta \beta^{\prime} v o v \tau \alpha$ as the ob-

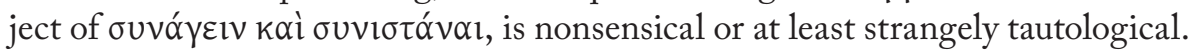
Turnèbe - both in a marginal note in his reading exemplar and in his edition tries to remedy this by taking the participle together with $\pi 0 \lambda \lambda \tilde{\omega} v$, thus reading $\alpha v \alpha \lambda \alpha \mu \beta \alpha v o ́ v \tau \omega v$, as his translation also testifies: 'cum per similitudine multa

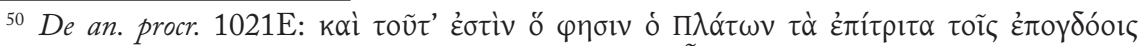

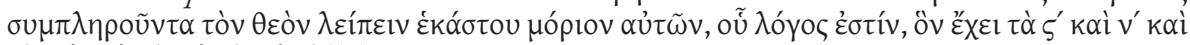

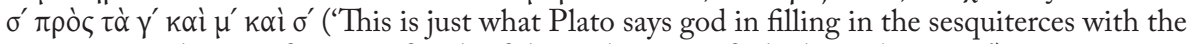
sesquioctaves leaves a fraction of each of them, the ratio of which is 256 to $243^{\prime}$ ). 
in unam se formam induant et potestatem ${ }^{\text {'51. }}$. It may be possible to interpret the active $\alpha v \alpha \lambda \alpha \mu \beta \alpha v o ́ v \tau \omega v$ in a medial sense, as seems to be Turnèbe's strategy $y^{52}$, but the solution is syntactically (how to account for ह̇k?) and philosophically (the unifying force is due to sameness, not to the 'multa') problematic. Cherniss' suggestion is certainly the correct one.

\section{CONCLUSION: À LA RECHERCHE DU TURNÈBE PERDU.}

Let us, finally, return to Montaigne. In the second edition of the Essais (1588) Montaigne adds praise for a rising star of humanism, who had not been mentioned in the first edition: the Leuven alumnus Justus Lipsius (1547 - 1606), who was at that time teaching in Leiden but would soon - in 1592 - return to Leuven to become one of the university's most famous professors ${ }^{53}$. According to Montaigne, Lipsius was the only worthy successor to Turnèbe: he is 'le plus sçavant homme qui nous reste, d'un esprit tres-poly et judicieux, vrayement germain à mon Turnebus ${ }^{54}$. Lipsius was only eighteen years old when Turnèbe died, but the Paris professor must have left a strong impression on the young scholar. In a 1587 letter to one of Turnèbe's sons, Lipsius speaks highly of the legacy of Turnèbe senior, 'vir divinus': 'ille vivet in summa aeternaque gloria, quamdiu res Graecae aut Romae'55.

I would not want to disagree with the judgement of one of Leuven's greatest classicists, who professed that Turnèbe will live as long as the study of Greek and Latin are alive. If this volume is one of many testimonies to the fact that classical scholarship is still very much alive, this paper may have been a minute call to resuscitate Turnèbe's legacy. Although his contributions are mentioned frequently in our current editions of De animae procreatione, the diverse nature of these contributions has - quite understandably, given the necessity to produce an economical apparatus criticus - been forgotten. Nevertheless, as the few examples discussed here have shown, this diversity is essential to our understanding of Turnèbe's thoughts on the constitutio textus.

Most importantly, it has become clear that, for Turnèbe, a translation was different from an edition. Since both appeared on the same day, it is quite unlikely that Turnèbe's opinion on the constitutio textus changed between the two publications. Therefore, it should be kept in mind that Turnebus editor is much

${ }^{51}$ Cf. the similar 'solution' in Xylander's translation: 'contrahere et compingere, ut multa ob similitudinem unam nanciscantur formam atque facultatem'.

${ }^{52}$ Cf. LSJ q.v. I.2: 'receive'.

${ }^{53}$ For a brief overview of Lipsius' life see e.g. Papy 2011.

${ }^{54}$ Essais II, 12 (p. 578 VS).

${ }^{55}$ Iusti Lipsi Epistolae [= ILE] II, 870316 (in Nauwelaerts and Sué 1983). Two letters from 1598, addressed to sons of Turnèbe, show that Lipsius' regard did not fade: ILE 980402 and ILE $980802 \mathrm{~T}$ (both in Deneire 2009). 
more conservative than Turnebus interpretor. Moreover, as we saw, adducing the translation as textual evidence should be done only very carefully, since Turnèbe's Ciceronian method of translation can give rise to misunderstandings. Another caveat is the difference between Turnebus lector and Turnebus editor: some discrepancies between the marginal notes in the Aldine copy - which, through the quite unreliable list in the 1599 edition, were the most influential source of Turnèbe's textual engagement with De animae procreatione - and the actual edition and translation. In the end, nothing can be more straightforward than our final conclusion: a set of reading notes, a translation and an edition are different things. Remaining aware of their difference, however, has turned out to be much less straightforward. 


\section{BiBLIOGRAPHY}

Editions and translation of Plutarch used (chronologically)

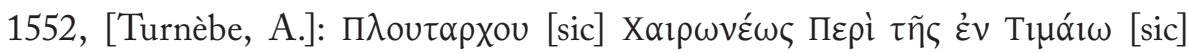
uvxoyovíac. Plutarchi Chaeronei De procreatione animi in Timaeo Platonis. Parisiis, apud Guil. Morelium. [Turnèbe's edition.]

1552, Turnèbe, A.: Plutarchi Chaeronei De procreatione animi in Timaeo Platonis Adriano Turnebo interprete. Parisiis, ex officina Adriani Turnebi Typographi Regis. [Turnèbe's translation.]

1570, Xylander, G.: Plutarchi Chaeronensis Moralia [...] Guilielmo Xylandro Augustano interprete [...] Basileae, per Thomam Guarinum.

1572, Stephanus, H.: Plutarchi Chaeronensis quae exstant opera, cum Latina interpretatione. Ex vetustis codicibus plurima nunc primum emendata sunt $[. .$.$] excudebat Henr. Stephanus [...].$

1574, Xylander, G.: Plutarchi Chaeronensis Philosophorum et Historicorum principis varia scripta [...] incredibili cura ac labore, \& fide summa, multis mendarum millib. expurgata, Indicib. locupletiss. instructa, a Guil. Xylandro [...] Basileae, per Eusebium Episcopium \& Nicolai Fr. haeredes.

1599, [Frankfurt edition, vol. 2]: Plutarchi Chaeronensis quae exstant omnia, cum Latina interpretatione Hermanni Cruserii: Gulielmi Xylandri, et doctorum virorum notis, et libellis variantium lectionum ex Mss. Codd. diligenter collectarum, et indicibus accuratis. Francofurti, apud Andreae Wecheli heredes [...] Tomus secundus, continens Moralia, Gulielmo Xylandro interprete.

1800, Wyttenbach, D.: Plutarchi Chaeronensis Moralia, id est opera, exceptis vitis, reliqua. [...] Tomus V. Oxonii, e typographo Clarendoniano. [This volume contains De an. procr.]

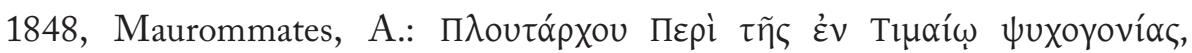

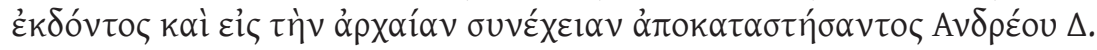

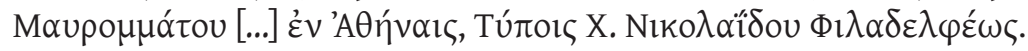

1873, Müller, B.: Gymnasium zu St. Elisabet. Bericht über das Schuljahr 18721873. [...] Plutarch über die Seelenschopfung im Timaeus [...], Breslau.

1841, Dübner, F.: Plutarchi Chaeronensis scripta moralia, ex codicibus quos possidet regia bibliotheca omnibus ab Kóv $\tau \omega$ cum Reiskiana editione collatis emendavit Fredericus Dübner. Graece et Latine. Volumen secundum. Parisiis, editoribus Firmin-Didot et sociis. 
1959, Hubert, C. and Drexler, H.: Plutarchi Moralia. Vol. VI. Fasc. 1. Recensuit et emendavit C. Hubert, additamentum ad editionem correctiorem collegit H. Drexler, Lipsiae. [Teubner]

1976, Cherniss, H.: Plutarch, Moralia. Volume XIII, part I, Cambridge (MA) - London. [Loeb Classical Library.]

2002, Ferrari, F. and Baldi, L.: Plutarco, La generazione dell'anima nel Timeo, Napoli. [Corpus Plutarchi Moralium.]

\section{OTHERS WORKS}

Becchi, F. (2009), 'Le traduzioni latine dei Moralia di Plutarco tra XIII e XVI secolo', in P. Volpe Cacciatore (ed.), Plutarco nelle traduzioni latine di età umanistica. Napoli, 11-52.

Cuvigny, M. (1973 [immo 1974]), 'Giannotti, Turnèbe, Amyot : résultats d'une enquête sur quelques éditions annotées des Moralia de Plutarque', Revue d'histoire des textes 3: 57-77.

Decorps-Foulquier, M. (1978 [immo 1979]), 'A propos des différentes écritures marginales dans l'exemplaire aldin des Moralia d'Adrien Turnèbe', Revue d'histoire des textes 8: 281-287.

___ (1982 [immo 1985]), 'Sur une interversion dans le De animae procreatione in Timaeo de Plutarque', Revue d'bistoire des textes 12: 353-363.

Deneire, T. (2009), Laconicae cuspidis instar. The Correspondence of Justus Lipsius: 1598. Critical Edition with Introduction, Annotations and Stylistic Study. Leuven.

Green, J.M. (1975), 'Montaigne's Critique of Cicero', Journal of the History of Ideas 36: 595-612.

Guerrier, O. (2004), 'Plutarque', in P. Desan (ed.), Dictionnaire de Michel de Montaigne. Paris, 922-925.

(2014), 'The Renaissance in France', in M. Beck (ed.), A Companion to Plutarch. Malden - Oxford - Chichester, 544-548.

Hubert, K. and Drexler, H. (1959), Plutarchi Moralia. Vol. VI. Fasc. 1. Leipzig.

Irigoin, J. (1987), 'Histoire du texte des Oeuvres Morales de Plutarque', in R. Flacelière, J. Sirinelli, A. Philippon, and J. Irigoin (eds.), Plutarque, Oeuvres Morales, I, 1. Paris, ccxxvii - cccx.

Kirk, G.S. (1954), Heraclitus. The Cosmic Fragments. Cambridge.

Konstantinovic, I. (1989), Montaigne et Plutarque. Genève.

Lewis, J. (1998), Adrien Turnèbe (1512 - 1565). A Humanist Observed. Genève.

Nauwelaerts, M.A. and Sué, S. (1983), Iusti Lipsi Epistolae. 2 : 1584-1587. Brussel. 
Opsomer, J. (2004), 'Plutarch's De animae procreatione in Timaeo: manipulation or search for consistency?', Bulletin of the Institute of Classical Studies 47: 137-162.

Papy, J. (2011), 'Justus Lipsius', in E.N. Zalta (ed.), The Stanford Encyclopedia of Philosophy.

Sturel, R. (1908), Jacques Amyot, traducteur des Vies parallèles de Plutarque. Paris.

Villey, P. and Saulnier, V.-L. (1988 [= 1965]), Montaigne. Les Essais. Paris.

Wyttenbach, D. (1795), Plutarchi Chaeronensis Moralia, id est opera, exceptis vitis, reliqua. Tomus I. Oxonii. 